\title{
Sekularisasi Menurut Pandangan Harvey Cox
}

\author{
Aluisius Dian Permana ${ }^{\text {a,1 }}$ \\ Ahmad Shalahuddin Mansur ${ }^{b, 2}$ \\ Program Magister Teologi Universitas Sanata Dharma, Yogyakarta a \\ Program Magister Teologi Universitas Kristen Duta Wacana, Yogyakarta ${ }^{\mathrm{b}}$ \\ dianpermanasj@gmail.com ${ }^{1}$ \\ ahmad.mansur@students.ukdw.ac.id ${ }^{2}$
}

\section{Keywords:}

Harvey Cox, sekularisasi, sekularisme, Gereja, Indonesia.

\begin{abstract}
Secularism has become a new trend in various parts of the world. Many people seem to no longer believe in the role of religion in the Society. Religion does not need to interfere with the situation that occurs in society. These problems raise different opinions and responses from various figures. Harvey Cox is one of the theologians who discusses secularization through his book entitled "The Secular City." Harvey Cox argues that secularization does not need to be rejected. Secularization is a process that occurs in society, where religious affairs are separated from community affairs. Secularization is clearly different from secularism. In secularism, people see religion as a stranger and God is seen as a barrier. Through the book "The Secular City", Harvey Cox offers a new perspective on secularization including how the Church should respond to secularization. This article will also briefly mention the secularization that has occurred in Indonesia. Nurcholish Madjid's thoughts illuminate the challenges and

hopes for the Indonesian.
\end{abstract}

\section{PENGANTAR}

Dalam sejarah manusia, permasalahan mengenai 'Allah' seakan tidak pernah habis. Sudah beberapa abad, perdebatan tentang eksistensi Allah tidak pernah usai dalam kehidupan manusia. Permasalahan tersebut disebabkan oleh beberapa faktor, misalnya pengaruh sains dan perkembangan teknologi dalam kehidupan manusia. Pada masa Abad Pertengahan, orang mengakui bahwa matahari mengelilingi bumi. Akan tetapi, pada abad XV ada seorang ilmuan yang bernama Nikolaus Copernicus (14731543) berpendapat bahwa bumi mengelilingi matahari atau matahari sebagai pusat tata surya. ${ }^{1}$ Dengan munculnya teori tersebut,

\footnotetext{
Robert S. Westman, "Nicolaus Copernicus", dalam https:// www.britannica.com/biography/Nicolaus-Copernicus, diakses tanggal 2 Juni 2020.
} 
teori geosentris digantikan oleh teori heliosentris. Karena teori tersebut, Nikolas Copernicus dianggap bidaah. Meskipun demikian, teori Nikolas Copernicus tidak menimbulkan konflik serius dengan Gereja. Hal ini disebabkan karena dalam bagian pengantar bukunya, Nikolas Copernius menjelaskan bahwa teori tersebut muncul untuk memudahkan perhitungan.

Pada abad ke-19, Gereja kembali diguncang dengan munculnya teori evolusi. Melalui bukunya yang berjudul The Origin of Species, Charles Darwin (1809-1882) menjelaskan tentang asal mula spesies. ${ }^{2}$ Oleh karena itu, menurut Charles Darwin, keberadaan manusia merupakan hasil dari evolusi kera. Manusia ada di dunia ini karena sebuah evolusi yang terjadi. Tentu, teori ini bertentangan dengan kepercayaan Kristen. Dalam Kitab Suci disebutkan bahwa manusia diciptakan oleh Allah menurut citra Allah. Manusia merupakan mahkluk ciptaan Allah dan bukan hasil dari sebuah evolusi kera. Dengan demikian, teori Charles Darwin sangat bertentangan dengan kepercayaan Kristen. Terlebih lagi, Charles Darwin mengingkari kisah penciptaan dalam Kitab Suci. Menghadapi hal ini, Gereja tidak tinggal diam saja. Gereja pernah mengeluarkan beberapa daftar ajaran yang dianggap sesat dan orang yang menganut ajaran tersebut dianggap sesat. Kenyataanya, para ilmuan terus bermunculan dan tidak jarang hasil pemikiran para ilmuan menambah wawasan bagi masyarakat. Para ilmuan bisa mencapai hal-hal baru yang sebelumnya tampak mustahil.

Manusia seakan diajak untuk terus bertanya, masih perlukah manusia percaya

\footnotetext{
Edward N. Zalta (ed.), "Charles Darwin", dalam https://www. famousscientists.org/charles-darwin/, diakses tanggal 2 Juni 2020.
}

kepada Allah jika kenyataannya manusia bisa mencapai hal-hal yang luar biasa tanpa peran Allah. Dalam era kita sekarang ini, banyak orang akan mengatakan bahwa Allah yang telah disembah berabad-abad oleh umat Yahudi, Kristen, dan Islam telah menjadi sejauh Allah Langit. Sebagian lainnya bahkan dengan terang-terangan mengklaim bahwa Allah telah mati. Salah satu alasan mengapa agama tampak tidak relevan pada masa sekarang adalah karena banyak di antara kita tidak lagi memiliki rasa bahwa kita dikelilingi oleh yang gaib. Kultur ilmiah kita telah mendidik kita untuk memusatkan perhatian hanya kepada dunia fisik dan material yang hadir di hadapan kita. Metode menyelidiki dunia seperti ini memang telah membawa banyak hasil. Akan tetapi, salah satu akibatnya adalah kita, sebagaimana yang telah terjadi, kehilangan kepekaan tentang yang 'spiritual atau suci' seperti yang melingkupi kehidupan masyarakat yang lebih tradisional pada setiap tingkatannya dan yang dahulumerupakan bagian esensial pengalaman manusia tentang dunia. ${ }^{3}$

Eksistensi Allah dalam hidup manusia seakan tidak diperlukan lagi bahkan ada kelompok-kelompok yang mengingkari keberadaan Allah, misalnya Karl Marx (18181883) berpendapat bahwa agama hanyalah sebuah 'candu' yang membuat manusia menjadi terlena dan tidak mau berjuang di dunia ini. Peran Allah seakan tidak lagi bermakna dan perlu 'dihilangkan' dari kehidupan manusia. Pada abad ke-19, ada beberapa pemikir yang beranggapan bahwa peran agama secara perlahan akan pudar dalam kehidupan manusia. Hal ini yang tidak jarang disebut dengan sekularisasi. Salah satu tokoh yang cukup menonjol yang membahas sekularisasi adalah Harvey

\footnotetext{
Karen Amstrong, Sejarah Tuhan (Bandung: Penerbit Mizan, 2001), 28.
} 
Cox. Melalui bukunya yang cukup terkenal, yaitu The Secular City (1965), Harvey Cox menguraikan pemikirannya tentang sekularisasi. Dalam tulisan ini, penulis hendak membahas konteks pemikiran Harvey Cox, gagasan penting Harvey Cox tentang sekularisasi, sekularisasi di Indonesia, dan dalam bagian akhir, penulis akan memberikan tanggapan.

\section{BIOGRAFI SINGKAT HARVEY COX}

Harvey Cox lahir pada tanggal 19 Mei 1929 di Malvern, Pennsylvania. Ayahnya bernama Harvey Gallager, seorang pelukis dan manager transportasi. Ibunya bernama Dorothea. Dari pernikahannya yang pertama, Harvey Cox dikaruniai tiga orang anak dan dari perkawinan yang kedua, ia dikaruniai satu anak. Harvey Cox menempuh pendidikan dasar di kota kelahirannya. Setelah itu, ia melanjutkan studinya di University of Pennsylvania dan memperoleh gelar sarjana dalam bidang sejarah pada tahun 1951 dan mendapat penghargaan. Selanjutnya, ia studi teologi di Yale Divinity School dan lulus pada tahun 1955 dengan predikat cum laude. Gelar doktoral dalam sejarah dan filsafat diperolehnya di University Harvard pada tahun 1963. Di tengah kesibukannya studi, Harvey Cox membantu American Baptist Home Mission Society pada tahun 1957. Selain itu, ia mulai mengajar di Andover Newton Theological School di Massachutetts sebagai asisten professor. Pada tahun 1965, ia mulai mengajar di Harvard Divinity School dan empat tahun kemudian ia diangkat sebagai professor penuh. Pada tahun 2009, Harvey Cox memutuskan untuk pensiun. ${ }^{4}$

4 Karena sedikit buku yang membahas tentang biografi Harvey Cox, maka penulis mengakses dari internet untuk
Harvey Cox mulai dikenal di antara para teolog setelah ia menulis buku yang berjudul The Secular City (1965). Buku tersebut sempat menjadi best-seller dan diterjemahkan ke dalam 11 bahasa. Namanya pun semakin melambung di Harvard. Melalui buku tersebut, secara garis besar, Harvey Cox menjelaskan tentang perlunya Gereja bersikap terbuka terhadap sekularisasi. Selain The Secular City, karya Harvey Cox yang cukup terkenal adalah The Feast of Fools: A Theological Essay on Festivity and Fantasy (1969), The Seduction of the Spirit: The Use and Misuse of People's Religion (1973), Religion in the Secular City: Toward a Postmodern Theology (1985), The Silencing of Leonardo Boff: The Vatican and the Future of World Christianity (1988), Fire from Heaven: The Rise of Pentecostal Spirituality and the Re-shaping of Religion in the 21st Century (1994), The Future of Faith (2009).

\section{PERKEMBANGAN SEKULARISASI DAN KONTEKS THE SECULAR CITY}

Permasalahan tentang sekularisasi dan sekularisme tidak dapat dilepaskan dari alam pikiran Barat karena mempunyai arti penting, sementara akar-akarnya berasal dari perkembangan filsafat serta ilmu pengetahuan dan teknologi di Barat. Pada abad ke-15 dan ke-16 yang dikenal sebagai zaman Renaisans, manusia di Barat tampaknya sudah tidak menghiraukan lagi agama Kristen, yang saat itu semakin berperan sentral. Renaisans (yang berarti kelahiran kembali), seolah mencerminkan suasana intelektual yang bebas, manusia

memperoleh sumber informasi, yaitu "Harvey Cox Facts", dalam https://biography.yourdictionary.com/harvey-cox, diakses tanggal 5 Juni 2020 dan "Cox, Harvey" dalam https:// www.encyclopedia.com/arts/educational-magazines/coxharvey-gallagher-jr-1929, diakses tanggal 5 Juni 2020. 
merasa dirinya dilahirkan kembali ke dalam suasana yang baru, ke suatu dunia baru, kemungkinan baru, kesadaran baru, dengan kekuasaan dan kekuatannya. Kemudian pada gilirannya manusia menempati kedudukan sentral dengan kekuatan rasionya. ${ }^{5}$

Manusialah yang merupakan tema terpenting pemikiran modern yang dipelopori oleh Decartes. ${ }^{6}$ Pemikiran tentang alam semesta dan rasionalitas menjadi dua ciri dari pemikiran Decartes. Menurut Decartes, alam semesta merupakan mesin raksasa. Alam tidak lain merupakan kumpulan materi yang bekerja berdasarkan struktur matematis. ${ }^{7}$ Dengan sendirinya, ada hukum yang bersifat mekanis, deterministik, holisitik, dan linear, yang mengatur alam semesta ini. ${ }^{8}$ Di sisi lain, rasio merupakan pusat manusia. ${ }^{9}$ Melalui rasio atau pikiran yang dioperasikan secara sistematis, berbagai hukum alam dapat ditentukan secara pasti. ${ }^{10}$ Secara politis, rasio pencerahan Barat telah berhasil merumuskan sejumlah hal sebagai basis etika berpolitik dalam sebuah demokrasi, seperti kebebasan beragama, penghormatan terhadap hak-hak asasi manusia dari semua orang, pemisahan dan kontrol atas kekuasaan. ${ }^{11}$ Ketajaman rasio pencerahan ini sendiri sanggup melihat keniscayaan syarat-syarat ini dan menjamin keberlangsungannya. ${ }^{12}$ Karena itu, Allah tidak diperlukan dalam kehidupan bersama. ${ }^{13}$ Allah didepak dari pertimbangan

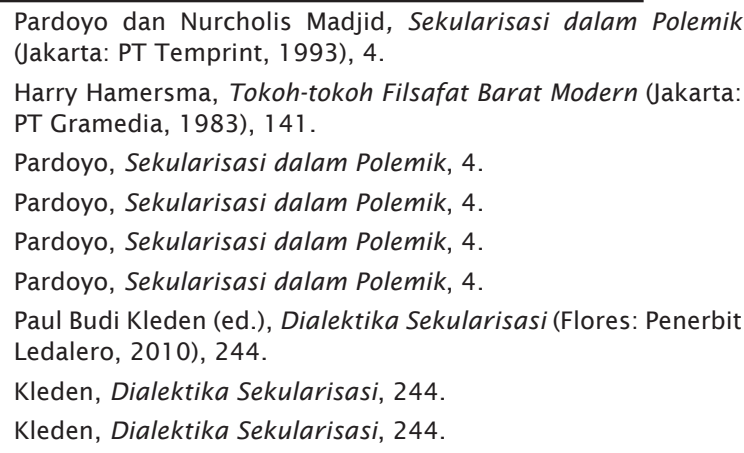

politik. ${ }^{14}$ Pembahasaan tentang alam semesta dan rasionalitas terus menarik dan seakan tidak pernah berkesudahan. Agama seperti tidak lagi menjadi topik yang menarik untuk dibahas. Bahkan pada pertengahan abad ke19, Auguste Comte juga telah meramalkan akan adanya kebangkitan ilmu-ilmu baru dan keruntuhan agama. ${ }^{15}$

Ternyata, globalisasi memengaruhi berkembangnya sekularisasi. Sebetulnya, secara derivatif, proses globalisasi merupakan perkembangan lebih lanjut dari zaman Aufklärung atau zaman Pencerahan di Eropa, yang merupakan tonggak acuan gelombang sejarah bagi ilmu pengetahuan dan teknologi. Zaman Aufklärung itu sendiri adalah kelanjutan dari Renaisans, yang merupakan reaksiyangmenggugat kejenuhan Abad Pertengahan dari dominasi agama (Gereja). Inti utama zaman Aufklärung adalah keyakinan bahwa manusia melalui kekuatan pengetahuannya akan dapat membangun dunianya sendiri yang lepas dari agama dan lepas dari Allah. Dengan kata lain, zaman Aufklärung merupakan zaman yang ditentukan secara dogmatik oleh dominasi pengetahuan manusia. Jika Abad Pertengahan diwarnai oleh dominasi keagamaan, maka zaman Aufklärung yang sudah termasuk abad modern ini diwarnai oleh dominasi ilmu pengetahuan. ${ }^{16}$

Dalam bukunya yang berjudul A Secular Age (2007), Charles Taylor mengatakan bahwa pada abad ke-19 telah tercipta suatu iklim bagi dirinya sendiri dalam bidang filosofis, sosiologis, politis, sastrawi, artistis, personal, di mana Allah menjadi tidak diketahui, suara-Nya tidak dapat didengar di antara keriuhan mesin-mesin dan

\footnotetext{
Kleden, Dialektika Sekularisasi, 244.

15 Pardoyo, Sekularisasi dalam Polemik, 6.

16 Pardoyo, Sekularisasi dalam Polemik, 145.
} 
modernitas. ${ }^{17}$ Ciri masyarakat itu sendiri yang urban, terindustrialisasi, materialistis, seakan menjadi latar belakang bagi masyarakat untuk tidak mengakui Allah. ${ }^{18}$ Gagasan tersebut seakan menjadi gambaran tentang apa yang terjadi pada zaman sekarang ini. Dunia bukan hanya masalah agama saja dan tidak semua masalah bisa diselesaikan dengan agama. Permasalahan inilah yang sering disebut sekularisasi. Akan tetapi, yang terjadi adalah seringkali orang kurang percaya lagi terhadap iman yang mereka peluk. ${ }^{19}$ Orang menjadi ragu akan imannya. ${ }^{20}$

Sekularisasi merupakan sebuah proses lepasnya berbagai bidang kehidupan masyarakat dari determinasi agama, misalnya norma-norma pengetahuan dan kekuasaan. ${ }^{21}$ Akibat proses itu bidang-bidang tersebut menjadi otonom dan beroperasi menurut mekanismenya sendiri. ${ }^{22}$ Tidak mengherankan bila kemudian kerap terjadi tegangan antara iman dan nalar, Gereja dan negara, urusan dunia dan akhirat. ${ }^{23}$ Perkembangan filsafat sebagai sebuah disiplin yang otonom tidak dapat dilepaskan dari proses sekularisasi ini. ${ }^{24}$ Sekularisasi telah menghasilkan apa yang disebut oleh Max Weber Entzauberung der Welt (hilangnya sihir dunia): hal-hal yang dulu dianggap penuh kekuatan gaib, sakral, dan misterius lama kelamaan kehilangan ciri gaib, sakral, dan misteriusnya karena semakin

\footnotetext{
17 Charles Taylor, A Secular Age (Cambrige: The Belknap Press of Harvard University Press, 2007), 551-552.

18 Taylor, A Secular Age, 552.

19 Paul Gilbert, "Secularization and Faith," Review of Ignatian Spirituality, No. 127, (2011): 20-24.

20 Gilbert, "Secularization and Faith", 20-24.

21 Budi Hardiman, "Berfilsafat dalam Batas-batas Nalar dan Iman: Kant, Hegel, Kierkegaard dan Kekristenan," Jurnal Ledalero, Vol. 11 No. 1 (2012): 30.

22 Hardiman, "Berfilsafat dalam Batas-batas", 30.

23 Hardiman, "Berfilsafat dalam Batas-batas", 30.

24 Hardiman, "Berfilsafat dalam Batas-batas", 30.
}

banyak mendapat penjelasan rasional. $^{25}$ Sekularisasi dengan Entzauberung der Welt itu bisa dinilai merugikan sekaligus menguntungkan. ${ }^{26}$

Kerugiannya adalah bahwa konsepkonsep teologis dengan kekayaan semantis itu direduksi menjadi konsep-konsep sekular yang hanya bersangkutan dengan kehidupan profan dan imanen manusia. ${ }^{27}$ Keuntungannya adalah dewasa ini kita sudah menikmati banyak hasil dari proses sekularisasi konsep-konsep teologis itu, khususnya dalam filsafat politik, sehingga tatanan sekular modern, yakni negara hukum demokratis, dapat dilibati oleh kelompokkelompok dari berbagai kepercayaan. ${ }^{28}$ Konsep hak-hak asasi manusia yang sekarang diterima di hampir semua negara di dunia ini merupakan hasil sekularisasi konsep-konsep yang semula berkembang dalam tradisi teologis Kristiani. ${ }^{29}$

Tentu, kecenderungan sekularisasi menjadi permasalahan substansial, dan menimbulkan reaksi yang dapat digambarkan sebagai berikut: ${ }^{30}$

1. Pembangunan maupun modernisasi merupakan proses perubahan yang tidak terelakan, bahkan telah menjadi tuntutan bangsa karena dengan pembangunan, umat manusia akan percaya pada falsafah: bahwa hari ini harus lebih baik daripada hari kemarin, hari esok lebih menjajikan, karena itu harus lebih baik daripada hari ini. Namun di sini, bagaimana agama harus merumuskan ideologinya dalam menghadapi proses perubahan?

\footnotetext{
$25 \quad$ Hardiman, "Berfilsafat dalam Batas-batas", 30. Hardiman, "Berfilsafat dalam Batas-batas", 31. Hardiman, "Berfilsafat dalam Batas-batas", 31. Hardiman, "Berfilsafat dalam Batas-batas", 32. Hardiman, "Berfilsafat dalam Batas-batas", 32. Pardoyo, Sekularisasi dalam Polemik, 8.
} 
2. Terhadap pengertian perubahan atau perkembangan, dalam hal ini antara agama yang satu dengan agama yang lain terdapat interpretasi yang berbeda. Ada yang mengatakan bahwa Kristen menerima perkembangan karena menurut penafsiran mereka, agama harus sesuai dengan perkembangan zaman, karena itu Injil harus diberi interpretasi yang sesuai dengan zamannya.

3. Karena masing-masing agama di dunia ini mempunyai karakter berbeda, reaksi masing-masing agama terhadap sekularisasi akan berbeda pula. Ada yang mudah menerima sekularisasi, namun ada pula yang sukar menerimanya. Karena itulah, pandangan antara penganut agama yang satu dengan penganut agama lain berbeda pula, walaupun terkadang ada satu garis pemikiran yang hampir sama. Akan tetapi, latar belakang iman biasanya sangat mempengaruhi pandangan itu.

Salah satu buku yang cukup populer yang membahas sekularisasi adalah The Secular City karya Harvey Cox. Buku The Secular City ditulis oleh Harvey Cox ketika Amerika Serikat dipimpin oleh Presiden John F. Kennedy. Pada awal tahun 1961, Kennedy terpilih menjadi Presiden Amerika Serikat yang ke-35. Ia terpilih sebagai presiden pada usianya yang ke-43 tahun dan merupakan presiden termuda kedua setelah Theodore Roosevelt. Hal yang cukup menarik adalah John F. Kennedy merupakan Presiden Amerika Serikat yang pertama kalinya dari kalangan Katolik Roma. Hal ini menimbukan pergunjingan di dalam benak masyarakat Amerika Serikat. Ada yang berpikiran bahwa jangan-jangan Amerika Serikat akan menjadi sangat tunduk terhadap keputusan Paus di Roma. Harvey Cox pun berpikiran demikian, ia merasa cemas akan hal tersebut. Oleh karena itu, dalam bukunya yang berjudul The Secular City, ia membahas John F. Kennedy untuk menjelaskan tentang pragmatisme. Selain itu, ia menjelaskan tentang Albert Camus dan mengkaitkannya dengan hal-hal profan. Bagi Harvey Cox, pragmatisme dan halhal profan merupakan dua ciri dari Kota Sekuler. ${ }^{31}$

Menurut Harvey Cox, pragmatisme sering dikaitkan dengan hasil tindakan tersebut. Tindakan tersebut dianggap berguna jika mendatangkan hasil. Oleh karena itu, orang-orang sekular tidak percaya pada hal yang tampak misteri atau gaib. Dunia ini mempunyai aturannya sendiri dan tidak ada kaitannya dengan kekuatan dewa-dewi atau Allah. Mereka lebih percaya pada tindakan nyata terutama tindakan yang mendatangkan hasil dari praktek tindakan tersebut. Profanitas sering dikaitkan dengan keduniawian. Orang-orang tersebut tidak melanggar kesucian agama, mereka hanya tidak religius. Bagi Harvery Cox, John Kennedy menjadi contoh orang yang menganut pragmatisme dan Albert Camus menjadi contoh orang yang menganut profanitas. ${ }^{32}$

Dalam pemerintahannya, ternyata, John F. Kennedy menggunakan cara yang pragmatis, termasuk dalam urusan politik. Ketika menghadapi masalah, ia berusaha mendekati masalah dengan pertimbanganpertimbangan tertentu, yang baginya mendatangkan hasil. John Kennedy seakanakan tidak banyak berbicara mengenai agama. Di sisi lain, menurut Cox, Albert Camus menjadi panutan bagi banyak orang yang tidak peduli dengan masalah agama. Ada semacam kontradiksi antara eksistensi

\footnotetext{
Harvey Cox, The Secular City (United States of America: Great Britain, 1965), 60-61.

32 Cox, The Secular City, 60-61.
} 
Allah dan tanggung jawab manusia. Bagi Camus, karena hidup ini absurd, maka manusia diajak bertanggung jawab terhadap diri sendiri dan mengabaikan peran Allah. Bagi Harvey Cox, John Kennedy dan Albert Camus menjadi contoh dalam Kota Sekuler. John Kennedy dianggap sekular dalam bidang politik dan Albert Camus dianggap sekular dalam bidang etika dan makna hidup manusia. ${ }^{33}$

Harvey Cox menulis The Secular City pada waktu Gereja mengadakan Konsili Vatikan yang kedua (1962-1965). Konsili tersebut dibuka oleh Paus Yohanes XXIII pada tanggal 11 Oktober 1962 dan ditutup oleh Paus Paulus VI pada tanggal 8 Desember 1965. Gereja menyadari kehadirannya di tengah-tengah masyarakat, maka Gereja pun berusaha memberikan tanggapan terhadap sekularisasi dalam Konstitusi Pastoral yang berjudul Gaudium et Spes (Kegembiraan dan Harapan). Oleh karena itu, dengan tegas dan jelas dinyatakan bahwa konsili ditujukan untuk semua orang: "Konsili Vatikan II tanpa ragu-ragu mengarahkan amanatnya bukan lagi hanya kepada putra-putra Gereja dan sekalian orang yang menyerukan nama Kristus, melainkan kepada semua orang. Kepada mereka semua, Konsili Suci bermaksud menguraikan bagaimana memandang kehadiran serta kegiatan Gereja pada masa kini." ${ }^{34}$

\section{SEKULARISASI TIDAK PERLU DITOLAK}

Dalam buku The Secular City, Harvey Cox membedakan istilah sekularisasi dan sekularisme. Secular berasal dari kata Latin saeculum, yang berarti masa kini (this age). ${ }^{35}$ Pengertian tersebut mengandung unsur ruang dan waktu. Ruang menunjuk pada pengertian duniawi, sedangkan waktu menunjuk pada pengertian sekarang. Dalam bahasa Yunani, seculer mengandung artimasa (age or epoch). ${ }^{36}$ Dengan kata lain, secular menunjuk pada situasi saat ini, tempat manusia berada. Dalam bahasa Yunani, dunia ini memiliki sejarahnya sendiri. Dunia ini merupakan ciptaan Allah dan menuju Kesempurnaan. Itulah pandangan orangorang Yunani bahwa hidup mengacu pada waktu sekarang, sedangkan orang-orang Yahudi berpendapat bahwa hidup di dunia ini hanyalah sementara dan akan menuju keselamatan setelah meninggal. ${ }^{37}$

Sekularisasi lebih bersifat open-ended, dalam arti menunjukkan sifat keterbukaan dan kebebasan bagi aktivitas manusia untuk proses sejarah. Maka sekularisme bersifat tertutup, dalam arti sudah bukan merupakan proses lagi, tetapi sudah merupakan suatu paham atau ideologi. Istilah sekularisme diperkenalkan pertama kali oleh George Jacob Holyoake pada tahun 1846. Menurut pendapatnya, sekularisme adalah suatu sistem etik yang didasarkan pada prinsip moral alamiah dan terlepas dari agamawahyu atau supranaturalisme. Manusia yang menganut paham sekularisme berusaha menikmati kehidupan dan kemajuan selama ini seolah-olah tanpa campur tangan Allah dan menganggap Allah tidak perlu lagi. Dalam sekularisme, orang melihat agama sebagai suatu yang asing dan Allah dilihat sebagai penghalang. ${ }^{38}$

Menurut Harvey Cox, sekularisasi merupakan sebuah proses yang terjadi di dalam masyarakat, di mana urusan agama

\footnotetext{
36 Cox, The Secular City, 18.

37 Cox, The Secular City, 18.

38 Pardoyo, Sekularisasi dalam Polemik, 21-22.
} 
dipisahkan dari urusan masyarakat. ${ }^{39}$ Agama tidak perlu ikut campur dalam permasalahan-permasalahan yang terjadi di masyarakat. Sekularisasi jelas berbeda dengan sekularisme. Bagi Harvey Cox, sekularisme adalah sebuah pandangan yang tidak mengakui adanya Allah. Sekularisme dengan jelas mengingkari keberadaan Allah. Oleh karena itu, istilah sekularisasi dan sekularisme tidak bisa disamakan begitu saja. Dalam sekularisasi, orang masih mengakui adanya Allah, tetapi semua permasalahan yang terjadi di dunia ini tidak bisa diselesaikan begitu saja dengan agama. ${ }^{40}$ Dalam hal ini, Harvey Cox mengambil contoh berbagai kejahatan dan krisis perkotaan yang terjadi di Boston. Kasuskasus kejahatan yang terjadi di Boston tidak semuanya bisa diselesaikan dengan masalah agama dan perlu campur tangan negara untuk menyelesaikannya.

Ternyata, sekularisasi dan sekularisme yang terjadi juga membawa dampak yang negatif dalam masyarakat. Dalam hal ini, Harvey Cox menyoroti munculnya majalah Playboy. ${ }^{41}$ Bagi Harvey Cox, munculnya majalah Playboy adalah akibat dari kemajuan industri perkotaan. Majalah Playboy terbit pertama kali pada tahun 1953 dan diketuai oleh Hugh Hefer. Setelah dicetak, majalah tersebut laris manis, dibeli oleh orang-orang yang rentang usianya 18 tahun sampai 30 tahun. ${ }^{42}$ Sayangnya, majalah tersebut terlalu vulgar. Manusia menjadi terlalu bebas dan mengeksploitasi seksualitas secara berlebihan demi keuntungan ekonomi. Bahkan secara keras, Harvey Cox mengatakan bahwa sistem ekonomi tampaknya membutuh-

\footnotetext{
Cox, The Secular City, 20-21.

Cox, The Secular City, 20-21.

Cox, The Secular City, 199.

Cox, The Secular City, 199.
}

kan penyimpangan seksualitas agar dapat bertahan secara terus menerus. ${ }^{43}$ Padahal seharusnya dalam Kota Sekuler orang perlu mendapatkan pemahaman dan pendidikan tentang moralitas. Moralitas diperlukan agar orang-orang dapat bertindak dalam batas-batas kewajaran. Memang ada negara yang menolak beredarnya majalah tersebut, misalnya Indonesia. Kenyataannya, kebebasan manusia membawa dampak positif dan negatif. ${ }^{44}$ Meskipun demikian, kebebasan tetap ada batas-batasnya dalam masyarakat. ${ }^{45}$ Dengan kata lain, dalam Kota Sekuler tanggung jawab manusia sangat diperlukan.

Berhadapan dengan hal ini, Harvey Cox berpendapat tentang pentingnya sebuah organisasi dalam masyarakat. Dalam organisasi ini perlu adanya sebuah prinsipprinsip yang jelas yang mengatur kehidupan masyarakat. Organisasi ini memiliki beberapa prinsip. Pertama, organisasi ini bersifat fleksibel. Artinya organisasi ini tetap terbuka terhadap kemungkinan dan segala tantangan zaman. Kedua, organisasi ini berorientasi pada masa depan. Organisasi ini mengusahakan sesuatu yang baik di dalam masyarakat. Ketiga, oganisasi ini bersifat sekular. Organisasi ini menolak segala bentuk ritual yang berhubungan dengan agama. Keempat, organisasi ini memilki jumlah anggota yang jelas. Setiap anggota diharapkan memiliki kontribusi yang baik untuk kehidupan yang lebih baik. Organisasi tersebut tetap memberikan kebebasan kepada masyarakat, tetapi masyarakat perlu bertanggung jawab dengan segala perbuatannya. ${ }^{46}$

\footnotetext{
3 Cox, The Secular City, 214.

$44 \quad$ Albert Borgmann, "Liberty, Festivity, and Poverty: Harvey Cox on Christianity and Technology," Philosophy Today Vol. XXX, No. 3/4, Fall (1986): 182.

45 Borgmann, "Liberty, Festivity, and Poverty", 182.

46 Cox, The Secular City, 176-177.
} 
Di sisi lain, pekerjaan setiap manusia perlu dipisahkan dari agama. ${ }^{47}$ Meskipun demikian, setiap pekerjaan perlu diberi makna untuk dirinya sendiri dan untuk orang lain. Kenyataannya, manusia tidak hanya berhadapan dengan agama saja dalam hidupnya, tetapi juga berhadapan dengan urusan-urusan dunia lainnya. Akan tetapi, manusia juga perlu menjunjung ketertiban bersama. Dengan demikian, dunia ini akan berjalan sesuai dengan aturan-aturan yang ada. Bagi Harvey Cox, sekularisasi bukan berarti meniadakan aturan dan moral dalam masyarakat. Manusia bisa saja memisahkan iman mereka dengan dunia, tetapi manusia tidak bisa memisahkan hidup mereka dengan tanggung jawabnya. Oleh karena itu, Harvey Cox cenderung memandang sekularisasi secara positif. Yang terpenting adalah, manusia bertanggung jawab dengan tindakannya dan negara tetap memberikan kontrol terhadap masyarakat.

\section{GEREJA PERLU 'TERBUKA'}

Dalam menanggapi sekularisasi, Harvey Cox menjelaskan tiga aspek yang penting, yaitu pembebasan alam dari ilusi (disenchantment of nature), desakralisasi politik (desacralization of politics), dan pembangkangan terhadap nilai-nilai (deconsecration of values). ${ }^{48}$ Pembebasan alam dari ilusi berarti pembebasan alam dari pengaruh Ilahi, entah itu anismistis, dewadewa, dan sifat magis dari alam. Alam perlu dipisahkan dari Allah. Desakralisasi politik dapat diartikan, bahwa agama tidak perlu ikut campur dalam urusan politik. Urusan politik tidak perlu dikaitkan dengan urusan agama. Perkembangan terhadap nilainilai berarti agama perlu bersikap terbuka terhadap perubahan yang diciptakan oleh manusia. Dengan demikian, kebebasan manusia tidak dibatasi. ${ }^{49}$

Menurut Harvey Cox, berhadapan dengan sekularisasi, Gereja perlu bersikap terbuka. Keterbukaan sikap Gereja ini terutama menyangkut perubahan sosial yang terjadi di dalam masyarakat. Bagi Harvey Cox, Gereja tidak perlu menutup diri, tetapi perlu mencari solusi dalam menyikapi sekularisasi. Oleh karena itu, para teolog perlu memikirkan hal ini dalam merumuskan teologi yang sesuai dengan konteks. Akan tetapi, Harvey Cox kurang setuju dengan Teologi Sejarah (theology of history) yang telah dikemukakan oleh para teolog. Teologi Sejarah lebih cenderung membahas tentang peristiwa-peristiwa historis dalam sejarah manusia. Di sisi lain, Teologi Sejarah lebih menunjuk peristiwa masa lampau dan tidak 'membahas' masa sekarang. Oleh karena itu, Harvey Cox menawarkan sebuah teologi baru, yaitu Teologi Perubahan Sosial (theology of social change). ${ }^{50}$

Bagi Harvey Cox, pendasarannya adalah Yesus Kristus datang kepada umat-Nya bukan terutama melalui tradisi gerejawi, tetapi melalui perubahan sosial. ${ }^{51}$ Oleh karena itu, gagasan Kota Sekuler seakan menjadi kritik terhadap Gereja yang tidak memberikan solusi kepada masyarakat modern sekarang ini. Dalam menyikapi sekulariasi, Harvey Cox menawarkan beberapa gagasan untuk Gereja. Gagasan tersebut menyangkut bidang kerygma, diakonia, dan koinonia. Dalam bidang kerygma, Gereja perlu memproklamasikan kedatangan tatanan hidup baru. Manusia diajak untuk tidak

$47 \quad$ Cox, The Secular City, 182.

48 Cox, The Secular City, 17. 
mudah percaya kepada nasib. Dengan kata lain, masa depan ada di tangan manusia dan bukan berdasarkan nasib. Oleh karena itu, ketika ada ketidakberesan dalam bidang ekonomi dan ketidakadilan sosial, manusia tidak berhak menyalahkan nasib. Ketidakadilan sosial perlu ditangani oleh manusia sendiri demi masa depan yang lebih baik. Dengan demikian, manusia tidak percaya pada nasib begitu saja. ${ }^{52}$

Dalam diakonia, Gereja perlu mempersonifikasikan arti tatanan hidup baru. Maksdunya adalah Gereja perlu terlibat dalam perbuatan penyembuhan dan perdamaian (healing the urban fractures). Gereja diharapkan ikut dalam pelayanan komunikatif. Dengan demikian, Gereja tidak menutup mata terhadap berbagai permasalahan yang terjadi. Bahkan Gereja diharapakan bisa memberikan solusi dan mangatasi persoalan-persoalan yang terjadi di dalam masyarakat. Dalam hal ini, Harvey Cox lebih menitikberatkan pada keutamaan Gereja sebagai pelayan. Memang segala permasalahan yang terjadi di dunia ini tidak semuanya bisa diatasi oleh Gereja, entah itu dalam politik, ekonomi, rasisme, sosial, dll, tetapi Gereja tetap diharapakan ikut terlibat dalam mencari solusi. ${ }^{53}$

Dalam koinonia, Gereja hendaknya ikut bertanggung jawab dalam Kota Sekuler. Tanggung jawab ini dapat dilakukan dengan mendemonstrasikan apa yang tertera dalam bidang kerygma dan diakonia. Harapannya adalah, Gereja menjadi teladan dalam Kota Sekuler. Lebih jauh lagi, kerygma dan diakonia bukan sebatas pembicaraan saja, tetapi dipraktekan secara nyata dalam kehidupan masyarakat melalui hal-hal yang konkret.

\footnotetext{
52 Cox, The Secular City, 127-132.

53 Cox, The Secular City, 132-144.
}

\section{TANGGAPAN JOSEPH RATZINGER}

Dalam buku The Secular City, sekularisasi seakan bukan hal yang baru dan telah menjadi bagian dalam sejarah manusia. Sekularisasi yang terjadi secara perlahan-lahan terus menghinggapi masyarakat. Ada yang menanggapi secara positif, tetapi ada juga yang menanggapi secara negatif. Menyikapi sekularisasi, Harvey Cox melihatnya secara positif. Kebebasan manusia tetap perlu dihargai, tetapi kebebasan perlu diatur. Manusia tetap diharapkan mengembangkan ide-idenya demi kemajuan masyarakat. Penulis sependapat, bahwa dalam hal ini, manusia tetap diharapkan bertanggung jawab atas tindakannya, termasuk dalam menggunakan akal budinya. Perlu dicermati bahwa segala urusan di dunia ini tidak bisa ditangani oleh agama. Bahkan agama tak jarang menimbulkan 'bahaya' bagi masyarakat. Oleh karena itu, agama juga ada batas-batasnya.

Dalam sejarah Kekristenan Eropa, Joseph Ratzinger menunjukkan tiga peristiwa penting dalam sejarah, yang membuktikan pentingnya mengaitkan agama dengan akal budi, agar agama tidak menjadi sumber legitimasi pembasmian kelompok-kelompok minoritas. Pertama, perjumpaan peradaban Kristen-Eropa dengan kebudayaan bangsabangsa Indian pada abad ke-16. Orang-orang Eropa menemukan satu bangsa, yang tidak beriman Kristen dan tidak memiliki kodeks moral Kristen. Apakah ini lalu berarti bahwa orang-orang Indian itu boleh diperlakukan sebagai orang-orang yang tidak memiliki hak? Peristiwa kedua terjadi pada masa Perang Tiga Puluh Tahun (1618-1648) yang menyusuli reformasi dalam Gereja pada abad ke-16. Perbedaan keyakinan di antara orang-orang Kristen membuktikan secara jelas bahwa orang tidak dapat lagi 
mengandalkan agama sebagai kesatuan. Orang memerlukan satu hukum, yang mendahului dan mengatasi dogma-dogma agama. Ketiga, peran akal budi di dalam agama-agama kembali ditegaskan kalau kita memperhatikan kebangkitan kesadaran manusia akan hak-hak dasarnya. Hak ini dimiliki seseorang tanpa rujukan pada ras, agama atau malah pada kualitas moralnya sendiri. ${ }^{54}$

\section{Gagasan Harvey Cox tentang Kota} Sekuler ada benarnya juga bahwa setiap bidang tidak perlu melulu dikaitkan dengan agama. Dengan kata lain, agama jangan dicampuradukan dengan setiap permasalahan yang terjadi apalagi dikaitkan dengan mitos-mitos atau supranatural. Manusia diajak untuk berpikir secara mandiri demi kemajuan hidup bersama dalam masyarakat. Hal tersebut juga perlu didukung oleh Gereja lewat tindakantindakan nyata. Bagaimanapun juga Gereja perlu mendukung dan memberikan teladan seperti apa yang disampaikan oleh Harvey Cox. Hanya saja terkadang tidak mudah menentukan bentuk-bentuk yang pas.

\section{SEKULARISASI DI INDONESIA}

Di bagian atas sudah dijelaskan tentang sekularisasi yang terjadi di Amerika Serikat. Lantas bagaimana dengan sekularisasi yang terjadi di Indonesia? ${ }^{55}$ Di Indonesia, persoalan sekularisasi telah menjadi polemik yang terutama berkutat pada masalah semantik, pada persoalan arti sekularisasi itu sendiri. ${ }^{56}$ Hal ini telah terjadi karena perbedaan sudut pandang. ${ }^{57}$ Persoalan ini

\footnotetext{
$54 \quad$ Kleden, Dialektika Sekularisasi, 222-223.

55 Dalam pembahasan ini, penulis lebih menitikberatkan pemikiran Nurcholish Madjid tentang sekularisasi di Indonesia.

56 Pardoyo, Sekularisasi dalam Polemik, 256.

57 Pardoyo, Sekularisasi dalam Polemik, 256.
}

telah menjadi perdebatan terutama pada dua dekade secara berturut-turut: ${ }^{58}$

1. Pada dekade 1970-an terjadi perdebatan antara Nurcholish Madjid (akrab disapa Cak Nur), sebagai seorang cendekiawan muslim yang dengan tiba-tiba melontarkan gagasan sekularisasi, dan para oposisiya. Ia sendiri dikecam baik oleh teman-temannya, maupun oleh para tokoh yang lebih senior seperti H.M. Rasjidi.

2. Pada dekade 1980-an muncul perdebatan antara Soenawar Soekowati, ketua umum DPP F-PDI, dan kelompok penentangnya. Soenawar melontarkan pernyataan bahwa Indonesia adalah negara sekuler. Ini dikecam oleh teman-temannya yang terutama di kalangan DPR.

3. Pada dekade 1980-an, Selo Soemardjan, seorang guru besar UI berpendapat bahwa pada tahun 2012 Indonesia akan mengalami sekularisme.

Dalam pandangan Yudi Latif, Islam di Indonesia tidak monolitik, melainkan plural, penuh warna. Tidak heran jika tanggapan atas proyek sekularisasi dan modernisasi di negara-negara Muslim di Timur Tengah berbeda dengan di Asia Tengah atau Asia Tenggara. Begitupun tanggapan Muslim dalam satu negara Muslim, juga bisa sangat beragam terhadap proyek sekularisasi dan islamisasi. ${ }^{59}$ Memang sekularisme telah dipahami sebagai upaya sengaja untuk mengeluarkan agama dari urusan-urusan dunia. Di satu sisi, Abdul Karim Soroush melihat pemerintah sekuler tidak semuanya menentang agama; pemerintah menerima agama tetapi sebagai dasar untuk legitimasi atas tindakan mereka. Setiap pemerintah, supaya tetap hidup dan bertahan,

\footnotetext{
$58 \quad$ Pardoyo, Sekularisasi dalam Polemik, 174.

59 Baca Yudi Latif, Dialektika Islam: Tafsir Sosiologis Atas Sekularisasi dan Islamisasi Indonesia, ed. Idi Subandi Ibrahim (Yogyakarta: Jalasutra, 2007).
} 
membutuhkan dua hal: sumber legitimasi dan kerangka normatif. ${ }^{60}$

Itulah sebabnya ada saja rezim sekular yang mempolitisasi agama atau mengangkat pemimpin agama paling tidak secara simbolik agar ia memiliki basis dukungan politik, terutama di sebuah negara di mana agama menjadi kekuatan simbolik dan kerangka normatif. Lebih lanjut, Soroush melihat bahwa dewasa ini pemerintah mendapatkan legitimasinya dari persetujuan rakyat yang diperintah, yang merupakan ciri pemerintahan sekuler-demokratis atau demokratis sekuler. Di Indonesia akan terlihat bagaimana politisasi agama makin menguat dengan menaikkan terus sentimen agama sebagai legitimasi.

Dari sini, partai politik yang mengusung tema "Islam" dan para politisi Islam di Indonesia, misalnya akan selalu memainkan "kartu" islamisasi, paling tidak sebagai wacana dalam kampanye atau perdebatan di parlemen atau bahkan di politik elektoral untuk menunjukkan bahwa mereka seolaholah memiliki kepedulian terhadap segmen rakyat/voters yang beragama Islam yang menjadi basis pendukungnya. Dalam konteks Indonesia, gagasan sekularisasi dengan jargon "Islam Yes, Partai Islam No" adalah gagasan yang begitu populer. ${ }^{61}$ Jargon ini sekaligus menjadi ajakan Cak Nur agar umat Islam mulai melihat kemandekankemandekan berpikir dan kreativitas yang telah terpasung oleh berbagai bentuk kejumudan. Karena itulah, ia menyarankan suatu kebebasan berpikir, pentingnya

\footnotetext{
60 Abdul Karim Soroush, Menggugat Otoritas dan Tradisi Agama, (Bandung: Mizan, 2002), 79.

61 Wacana Cak Nur tentang sekularisasi ini sebenarnya dalam lingkup internasional-tidak sendirian, penggambaran tentang wacana sekularisasi di Dunia Islam lain. Lih. J.W.M Bakker S.J. "Sekularisasi dalam Pandangan Umat Islam," Orientasi (1973). J.W.M Bakker menganggapnya sebagai masa depan Islam. Bakker sangat menyambut pemikiran Cak Nur ini dan menganggapnya sebagai masa depan Islam.
}

the idea of progress, sikap terbuka, dan kelompok pembaruan yang liberal, yang bisa menumbuhkan -istilah Cak Nur sendiri- psychological striking force yang menumbuhkan pikiran-pikiran segar. ${ }^{62}$

Jika menelisik gagasan Cak Nur tentang sekularisasi ini, sebenarnya yang dimaksud pada mulanya adalah "devaluasi" atau "demitologisasi" atas apa saja yang bertentangan dengan tauhid, yaitu pandangan yang paling asasi dalam Islam. Jargon Cak Nur yang terkenal, "Islam, Yes, Partai Islam, No"-misalnya mau mengatakan, partai Islam itu (sekarang) bukan hal esensial, dan (sama sekali) tidak berhubungan dengan esensi ke-islam-an. Itulah makna "sekularisasi", yaitu mengembalikan mana yang sakral, sebagai sakraldan yang profan, sebagai profan. Politik Islam yang tadinya dianggal "sakral", yaitu bagian dari perjuangan Islam, sekarang "didesakralisasi".

Pada kenyataannya, ide Cak Nur ini terus bergulir dan sempat menjadi polemik dan menobatkan Cak Nur sebagai tokoh yang kontroversial. Memang kita perlu memahami lebih dalam latar belakang sosiologis yang mendorong Cak Nur menggunakan kata kunci sekularisasi sebagai upayanya untuk "pembaruan pemikiran Islam". ${ }^{63}$

Hal lain yang ingin Cak Nur tanggapi dalam konteks Indonesia, khususnya ketika wacana sekularisasi mulai bergulir pada tahun 1970, adalah bagaimana menyelamatkan umat Islam dari pemojokan gerakan Islam oleh Pemerintah Orde Baru. Sasarannya adalah agar umat Islam tidak lagi memperjuangkan gagasan negara

\footnotetext{
$62 \quad$ Budhy Munawar Rahman, Ensiklopedi Nurcholish Madjid, ed. Ahmad Gaus AF, et.al. (Bandung: Mizan, 2006), Ixi.

63 Budhy Munawar Rahman, Ensiklopedi Nurcholish Madjid, ed. Ahmad Gaus AF, et.al, (Bandung, Mizan, 2006), Ixv. Baca juga Nurcholish Madjid, Islam, Kemodernan, dan Keinonesiaan, (Bandung, Mizan, 1987), 240-266.
} 
Islam yang bertentangan dengan Pancasila dan UUD 1945 dan lalu mengarahkan wacananya ke gagasan keadilan sosial. Namun yang terjadi malah sebaliknya, yang lebih tampak belakangan adalah "Kembali kepada Piagam Jakarta" yang kemudian menghasilkan perda-perda Syari'ah dalam konteks otonomi daerah di beberapa kota di Indonesia.

Dawam Rahardjo berpendapat, kunci keberhasilan melahirkan perda-perda Syari'ah tersebut justru terletak pada partai-partai sekular yang memakai aturan main demokrasi. Di lain pihak, lahirlah partai-partai yang berlatar belakang gerakan Islam, tetapi dalam kenyataannya menganut sekularisme. Meski di tingkat wacana sekularisme ditolak keras, namun pada realitanya justru sedang berlangsung proses tersebut. Persoalan yang muncul selanjutnya adalah jika sekularisme tidak dipahami umat Islam di Indonesia, akan semakin banyak muncul kelompok-kelompok agama yang menolak sistem demokrasi. Di samping itu, kelompok-kelompok tersebut masih menganggap bahwa Pancasila, UUD 1945, NKRI dan Bhineka Tunggal Ika belum final bagi Indonesia. ${ }^{64}$

Oleh karenanya, Cak Nur menjelaskan sekularisasi bukan dimaksudkan sebagai penerapan sekularisme. Sekularisasi bukan dimaksud untuk mengubah kaum muslimin menjadi sekuler, tetapi untuk menduniawikan nilai-nilai yang semestinya sudah bersifat duniawi, dan melepaskan umat Islam dari syirik dan takhayul. Dengan demikian, sekularisasi dimaksudkan untuk memantapkan dan memutlakan Allah semata-mata (Tauhid). Untuk itu, sekularisasi memperoleh maknanya yang

\footnotetext{
64 M. Dawam Rahardjo, "Kata Pengantar" Reorientasi Pembaruan Islam: Sekularisme, Liberalisme, dan Pluralisme Paradigma Baru Islam Indonesia (Jakarta: LSAF, 2010), xxxxvi-xxxvii.
}

konkret, yakni sebagai desakralisasi. Cak Nur berpendapat bahwa sekularisasi di sini digunakan dalam arti sosiologis, yakni diarahkan pada pengertian pembebasan masyarakat (umat Islam) dari belenggu takhayul. Dengan begitu, istilah sekularisasi di sini tidak berarti penghapusan nilai-nilai agama, melainkan justru menumbuhkan semangat keagamaan. Sebagai pokok pemikirannya, Nurcholish menganjurkan sekularisasi, bukan sekularisme. ${ }^{65}$

Pemikiran dari Nurcholish Madjid tentang sekularisasi ini sedikit banyak dipengaruhi dari Talcott Parsons, Harvey Cox, dan Robert N. Bellah. ${ }^{66}$ Dalam uraian sebelumnya sudah dibahas bahwa dalam sekularisasi ada tiga aspek yang dikemukakan oleh Harvey Cox, yaitu pembebasan alam dari ilusi (dissenchanment of nature), desakralisasi politik (desacralization of politics), dan pembangkangan terhadap nilai-nilai (deconsecration of values). Dalam logika Cak Nur tentang sekularisasi dalam Islam, dikatakan bahwa Islam menekankan penggunaan rasio untuk mempelajari ayat-ayat yang terdapat dalam alam ini. Ia menganjurkan rasionalisasi, tetapi bukan rasionalisme. ${ }^{67}$ Begitu pula Islam menganjurkan sekularisasi, tetapi bukan sekularisme. ${ }^{68}$ Sekularisme dan rasionalisme itu sudah bukan cara berpikir lagi, tetapi sudah merupakan paham atau ideologi (yang notabene tertutup). ${ }^{69}$

Hal lain yang menjadi pertimbangan Cak Nur adalah jumlah mayoritas orang Indonesia beragama Islam, sehingga nilai

\footnotetext{
65 Pardoyo, Sekularisasi dalam Polemik, 256-257.

66 Pardoyo, Sekularisasi dalam Polemik, 93. Lihat juga, Budhy Munawar Rahman, Ensiklopedi Nurcholish Madjid, ed. Ahmad Gaus AF, et.al, (Bandung: Mizan, 2006), 2968-2969.

67 Pardoyo, Sekularisasi dalam Polemik, 95.

68 Pardoyo, Sekularisasi dalam Polemik, 95.

69 Pardoyo, Sekularisasi dalam Polemik, 95.
} 
yang paling baik mewarnai adalah nilai Islam. ${ }^{70}$ Oleh karena itu, Cak Nur lebih fokus ke sekularisasi. Ia melihat bagaimana saat ini masyarakat justru berada pada pasca-sekuler. Cak Nur-sebagaimana yang ditulis Budi Hardiman melihat Islam sudah menyatu di ruang publik di Indonesia (sebagai sebuah negara) ${ }^{71}$, Islam sudah menjadi "Sacred Canopy" (meminjam istilah Peter L. Berger) di Indonesia. Dari sini, nilai-nilai Islam yang dapat berlaku pada tataran nasional, hanyalah nilai Islam yang bisa diterima oleh semua pihak, dan orang Islam yang sanggup merumuskannya secara moderat, universal, serta inklusivistik. ${ }^{72}$

Pada akhirnya, Cox dan juga Cak Nur sama melihat bahwa proses sekularisasi terus terjadi juga di Indonesia yang mayoritas beragama Islam, khususnya pasca gagasan Cak Nur dan juga Gus Dur yang notabene tidak sepakat dengan gagasan formalisasi syari'at alias Islam Politik, seperti yang dikampanyekan oleh kelompok Islam tertentu di Indonesia. Dalam gagasannya tentang sekularisasi, Cak Nur juga pernah menanggapi buku karangan Harvey Cox, Secular City. Menurutnya, kesulitan yang timbul dari kenyataan bahwa masa enlightenment Eropa telah melahirkan filsafat sekularisme sebagai suatu ideologi yang secara khusus bersemangat anti-agama. Karenanya, cukup sulit untuk menentukan kapan proses sekularisasi, dalam makna sosiologisnya, berhenti dan berubah menjadi proses penerapan sekularisme filosofis.

Dari sini, Cak Nur menyadari dasar penolakan Rasjidi atas penggunaan istilah

\footnotetext{
$70 \quad$ Nurcholish Madjid, Dialog Keterbukaan Jakarta: Penerbit Paramadina, 1998), 171.

71 F. Budi Hardiman, "Nurcholish Madjid: Islam and Pluralistic Democracy in Indonesia", Verbum SVD Vol. 56:1-2, (2015), 189.

72 Madjid, Dialog Keterbukaan, 171.
}

sekularisasi. Jika benar dugaan ini, maka keberatan Rasjidi cukup beralasan dan dapat diterima, yaitu jika sekularisasi memang tak mungkin lepas dari sekularisme filosofis, dari Pencerahan (enlightenment) Eropa. Pada akhirnya, terdapat perbedaan prinsipal antara pengertian "sekularisasi" secara sosiologis dan secara filosofis. Dewasa ini, tengah arus global dan perkembangan ilmu pengetahuan, teknologi, dan kompleksnya permasalahan yang terus muncul, sekularisasi akan terus berlangsung, khususnya di Indonesia. Meskipun arus kelompok tertentu yang memainkan sentimen politik identitas agama terus terjadi di Indonesia. Sentimen tersebut seringkali digunakan untuk mendapatkan kekuasaan sehingga menumbalkan semangat persatuan.

\section{PENUTUP}

Berhadapan dengan sekularisasi, Gereja sebetulnya tidak tinggal diam begitu saja. Dalam Gaudium et Spes sudah ditegaskan bahwa Gereja menghargai kebebasan manusia:

"Bila yang kita maksudkan dengan otonomi hal-hal duniawi ialah bahwa makhluk-makhluk dan masyarakat sendiri mempunyai hukum-hukum serta nilainilainya sendiri, yang sedikit demi sedikit harus dikenal, dimanfaatkan, dan makin diatur oleh manusia, maka memang sangat pantaslah menuntut otonomi itu. Otonomi itu bukan hanya dituntut oleh orang-orang zaman sekarang, melainkan selaras juga dengan kehendak Sang Pencipta. Sebab berdasarkan kenyataannya sebagai ciptaan, segala sesuatu dikaruniai kemandirian, kebenaran, dan kebaikannya sendiri, lagi pula menganut hukum-hukum dan mempunyai tata sususannya sendiri. Dan 
manusia wajib menghormati semua itu, dengan mengakui metode-metode yang khas bagi setiap ilmu pengetahuan dan bidang teknik. Maka dari itu, penyelidikan metodis di semua bidang ilmu, bila dijalankan secara sungguh ilmiah dan menurut kaidah-kaidah kesusilaan, tidak pernah akan sungguh bertentangan dengan iman, karena hal-hal profan dan pokok-pokok iman berasal dari Allah yang sama."73

Gereja menghargai kebebasan manusia, tetapi sayangnya kebebasan manusia kelewat batas. Bahkan dengan terang-terangan manusia mengingkari keberadaan Allah. Hidup sudah berjalan sedemikian rupa sehingga tidak perlu lagi membahas Allah. Ini juga yang menjadi keprihatinan Gereja:

"bila 'otonomi hal-hal duniawi' diartikan seolah-olah ciptaan tidak tergantung dari Allah, dan manusia dapat menggunakannya sedemikian rupa sehingga tidak lagi menghubungkannya dengan Sang Pencipta, maka siapapun yang mengakui Allah pasti merasa juga, betapa sesatnya anggapan-anggapan semacam itu. Sebab tanpa Sang Pencipta, makhluk lenyap hilang. Selain semua itu, orang beriman, termasuk agama mana pun, selalu mendengarkan suara serta pewahyuanNya dalam bahasa makhluk-makhluk."74
Kenyataannya, sekularisasi memberikan dampak positif dan negatif dalam masyarakat. Dampak positifnya adalah segala urusan di dunia ini tidak melulu dinilai dari sudut pandang agama. Dampak negatifnya adalah takjarang seseorang bertindak kelewat batas. Menyikapi hal tersebut, bagaimanapun juga moral dan tanggung jawab manusia tetap diperlukan. Apa jadinya dunia ini jika seseorang tidak menggunakan moral dan tangggung jawabnya sebagai manusia? Manusia tetap perlu menghargai hak dan kebebasan diri sendiri maupun orang lain.

Sekularisasi tidak perlu mendapat penolakan. Hal ini akan mendorong keterbukaan Gereja, mendorong untuk meletakkan segala hal duniawi tetap pada posisinya, tetapi disinari oleh terang agama atau keyakinan. Sama halnya dengan konteks Indonesia, Islam turut mewarnai ruang-ruang publik meski di satu sisi disempitkan oleh kekuatan kelompok Islam fundamental sebagai kekuatan politik kekuasaan. Sekularisasi yang diserukan Cak Nur dalam konteks Indonesia selanjutnya mengembalikan semangat tauhid yang murni, yakni sebagai alat pembebasan sekaligus menjadi kritik kepada gerakangerakan Islam politik yangjustru menjauhkan spirit Islam yang sejati. Meskipun demikian, sekularisasi tetap menjadi tantangan pada masa sekarang ini yang perlu disikapi secara bijak dalam zaman yang bergerak dinamis.

\footnotetext{
$73 \quad$ Gaudium et Spes, art. 36.

74 Gaudium et Spes, art. 36.
} 


\section{DAFTAR RUJUKAN}

Amstrong, Karen. Sejarah Tuhan. Bandung: Penerbit Mizan, 2001.

Borgmann, Albert. "Liberty, Festivity, and Poverty: Harvey Cox on Christianity and Technology", Philosophy Today Vol. XXX, No. 3/4, Fall (1986).

Barone, Robert John. The Secularization Theology of Harvey Gallagher Cox. Romae, 1971.

Cox, Harvey. The Secular City. United States of America: Great Britain, 1965.

Hamersma, Harry. Tokoh-tokoh Filsafat Barat Modern. Jakarta: PT Gramedia, 1983.

Hardiman, Budi. "Berfilsafat dalam Batas-batas Nalar dan Iman: Kant, Hegel, Kierkegaard dan Kekristenan", Jurnal Ledalero, Vol. 11 No. 1 Juni (2012).

Hardiman, F. Budi. "Nurcholish Madjid: Islam and Pluralistic Democracy in Indonesia”, Verbum SVD Vol. 56:12. (2015).

Gilbert, Paul. "Secularization and Faith", Review of Ignatian Spirituality, No. 127 (2011).

Kleden, Paul Budi (ed.), Dialektika Sekularisasi. Flores: Penerbit Ledalero, 2010.
KWI. Dokumen Konsili Vatikan II (terj. R. Hardawiryana). Jakarta: Obor, 2008.

Latif, Yudi. Dialektika Islam: Tafsir Sosiologis Atas Sekularisasi dan Islamisasi Indonesia, ed. Idi Subandi Ibrahim. Yogyakarta: Jalasutra, 2007.

Madjid, Nurcholish. Dialog Keterbukaan. Jakarta: Penerbit Paramadina, 1998.

Madjid, Nurcholish. Islam, Kemodernan. dan Keinonesiaan. Bandung: Mizan, 1987.

Pardoyo dan Nurcholis Madjid. Sekularisasi dalam Polemik. Jakarta: PT Temprint, 1993.

Rahman, Budhy Munawar. Ensiklopedi Nurcholish Madjid, ed. Ahmad Gaus AF, et.al. Bandung: Mizan, 2006.

Rahman, Budhy Munawar. Reorientasi Pembaruan Islam: Sekularisme, Liberalisme, dan Pluralisme Paradigma Baru Islam Indonesia. Jakarta: LSAF, 2010.

Soroush, Abdul Karim Menggugat Otoritas dan Tradisi Agama. Bandung: Mizan, 2002.

Taylor, Charles. A Secular Age. Cambrige: The Belknap Press of Harvard University Press, 2007. 